EXPERIMENTAL STUDY

\title{
Unaltered pancreatic islet blood perfusion in islet amyloid polypeptide-deficient mice
}

\author{
Per-Ola Carlsson, Ella Karlsson, Hindrik Mulder ${ }^{1}$ and Samuel Gebre-Medhin ${ }^{2}$ \\ Department of Medical Cell Biology, Uppsala University, Uppsala, Sweden, ${ }^{1}$ Department of Cell and Molecular Biology, Section for Molecular Signaling and \\ ${ }^{2}$ Department of Physiological Sciences, Division for Molecular and Cellular Physiology, Lund University, Lund, Sweden
}

(Correspondence should be addressed to Per-Ola Carlsson, Department of Medical Cell Biology, Biomedical Center, Box 571, SE-751 23 Uppsala, Sweden; Email:Per-Ola.Carlsson@medcellbiol.uu.se)

\begin{abstract}
Objective: Several biological activities have been ascribed to islet amyloid polypeptide (IAPP). However, their physiological relevance remains unclear. Previous studies in rats with exogenous administration of IAPP suggest that the peptide may increase splanchnic vascular resistance and redistribute the blood flow within the pancreas to the islets. In this study, the use of IAPP-deficient mice allowed us to evaluate possible effects of the lack of IAPP on splanchnic blood perfusion and we could thereby circumvent the potentially pharmacological actions of exogenously administered IAPP.

Design: Regional splanchnic blood flow was measured after exogenous administration of IAPP and in IAPP-deficient mice.

Methods: Blood flow values were determined using a non-radioactive microsphere technique in anesthetized animals.

Results: No differences in whole pancreatic blood flow or islet blood flow could be detected in IAPPdeficient mice when compared with control mice; neither did IAPP deficiency affect the glucoseinduced increase in islet blood flow. Duodenal, ileal and colonic blood flows were similar in IAPPdeficient and control mice. Exogenous administration of IAPP selectively increased islet blood flow in wild-type control mice.

Conclusions: The present findings in the IAPP-deficient mice suggest that the vascular effects seen in the islets after exogenous administration of IAPP to normal mice reflect pharmacological, rather than physiological effects of the peptide. We conclude that the lack of endogenous IAPP within the splanchnic vascular system does not alter the blood perfusion of pancreatic islets or other splanchnic organs.
\end{abstract}

European Journal of Endocrinology 146 107-112

\section{Introduction}

Ever since the discovery of islet amyloid polypeptide (IAPP; also known as amylin) as the major constituent of amyloid deposits in a human insulinoma $(1,2)$ and in islets from patients with type 2 diabetes (3), the physiological role of this $\beta$-cell peptide (4) has remained enigmatic $(5,6)$. Several studies have suggested that IAPP restrains glucose handling in skeletal muscle $(7,8)$, and increases hepatic glucose output (9). A role for IAPP in the regulation of food intake (10) and gastric emptying (11) has also been suggested. Furthermore, possible effects of IAPP on insulin secretion have been extensively investigated (12-15); most studies have shown an inhibitory effect of IAPP on insulin release $(12-15)$. However, the high concentrations of IAPP required, together with uncertainties about the structure and tissue distribution of IAPP receptors, question the physiological relevance of the results (16). Recently, the generation and phenotypic analysis of mice with a targeted disruption of the IAPP gene have shed some light on the physiological role of IAPP in islets (17, 18). IAPP-deficient mice are euglycemic during basal conditions, but show an accelerated rate of glucose disposal during hyperglycemia, mainly due to a concomitant augmentation of the glucose-stimulated insulin response. This demonstrates indirectly that IAPP under physiological conditions does indeed restrain glucose-induced insulin release.

IAPP has also been implicated in the control of regional blood perfusion $(19,20)$, for example in the islets (21). It is possible that IAPP, which is stored with insulin in $\beta$-cell secretory vesicles (22) and released in conjunction with insulin in response to $\beta$ cell secretagogues (23), may exert a local control on islet blood flow (cf. 21). In the present study, the use 
of IAPP-deficient mice allowed us to examine the blood perfusion of the pancreatic islets and other splanchnic organs when endogenous IAPP is lacking, thereby potentially resolving the issue of physiological versus pharmacological effects of exogenously administered peptide. Here, the effects of exogenous administration of IAPP on islet blood flow were confirmed, whereas no alterations of islet blood flow were observed in IAPP-deficient mice.

\section{Materials and methods}

\section{Animals}

Wild-type $(+/+)$ and IAPP-deficient $(-/-)$ 3-month-old male 1290la/C57BL/6J hybrid mice were used in all experiments. As previously described (17), the IAPPdeficient mice were produced by disruption of the IAPP gene using targeted mutagenesis in embryonic stem cells (24). Briefly, the IAPP gene was disrupted by deletion of a major part of exon 3, which encodes the mature peptide (25). Deficient IAPP expression in IAPP $(-/-)$ mice was confirmed by the lack of exon 3 in genomic DNA subjected to Southern hybridization and by the lack of IAPP-like immunoreactivity in the pancreatic islets (17). The animals were bred at the Transgenic Core facility at Göteborg University, and had free access to autoclaved tap water and pelleted food throughout the course of the study. All mice were randomly assigned to the different experiments. The experiments were approved by the local animal ethics committee at Uppsala University.

\section{Blood flow measurements and assessment of islet volume}

The blood flow was determined with a microsphere technique, as previously described and evaluated (26). Briefly, the animals were anaesthetized with an intraperitoneal injection of $0.02 \mathrm{ml}$ Avertin/g body weight (a $2.5 \%(\mathrm{v} / \mathrm{v})$ solution of $10 \mathrm{~g} \mathrm{97 \%} \mathrm{(v/v)} \mathrm{2,2,2-tribromo-}$ ethanol (Sigma, St Louis, MO, USA) in $10 \mathrm{ml}$ 2-methyl2-butanol (Kemila AB, Stockholm, Sweden)), heparinized and placed on an operating table maintained at body temperature $\left(38^{\circ} \mathrm{C}\right)$. Polyethylene catheters were inserted into the ascending aorta via the right carotid artery, and into the right femoral artery. The former catheter was connected to a pressure transducer (PDCR 75; Druck, Groby, Leics, UK) for continuous monitoring of the mean arterial blood pressure, which was allowed to stabilize for $10-15 \mathrm{~min}$. In the first set of experiments using only control animals, rat IAPP $(85 \mathrm{nmol} / \mathrm{kg})$ dissolved in $0.2 \mathrm{ml}$ saline or saline alone was injected intravenously. In the second set of experiments, using both control and IAPP (-/ -) mice, $0.25 \mathrm{ml} 30 \%$ (wt/vol) d-glucose or saline was injected intravenously. Approximately $9 \times 10^{4}$ non-radioactive microspheres (NEN-Trac; DuPont
Pharmaceuticals, Wilmington, DE, USA) with a diameter of $11 \mu \mathrm{m}$ were injected 30 (1st set of experiments) or $15 \mathrm{~min}$ (2nd set of experiments) later during $10 \mathrm{~s}$ via the aortic catheter. Starting $5 \mathrm{~s}$ before the microsphere injection, and continuing for a total of $60 \mathrm{~s}$, an arterial blood reference sample was collected by free flow from the femoral catheter at a rate of approximately $0.10 \mathrm{ml} / \mathrm{min}$. The exact withdrawal rate in each experiment was determined by weighing the sample.

Arterial blood was then collected from the femoral catheter for determination of blood glucose concentrations with test reagent strips (Medisense; Baxter Travenol, Deerfield, IL, USA) and for serum insulin determinations with a radioimmunoassay (Insulin RIA kit; Pharmacia-Upjohn Diagnostics, Uppsala, Sweden) using a rat insulin standard (Novo Research Institute, Bagsværd, Denmark). The RIA kit used for serum insulin measurements had both an intra-assay and an interassay variability of less than $5 \%$.

The animals were killed and the whole pancreas, the adrenal glands, and parts of the duodenum (proximal part), ileum (distal part) and colon (descending part) were dissected free from fat and lymph nodes, blotted, weighed, and placed between object slides. Before placement between object slides each pancreas was cut into 20-24 pieces. The islets were visualized by a freezethawing technique (27), and the islet volume percentage was determined by a point-counting method (26, $28)$. For this purpose, the number of intersections overlapping islets was counted at a magnification of $\times 400$ in a stereo microscope equipped with both dark and bright field illumination (Wild M3Z; Wild Heerbrugg Ltd, Heerbrugg, Switzerland). Approximately 20-24 different fields were counted in each mouse pancreas (corresponding to 2400-2900 points).

The total number of microspheres in the exocrine and endocrine parts of the pancreas, intestines and adrenal glands was then estimated with the aid of a stereo microscope (26). The number of microspheres in the arterial reference sample was determined by transferring the blood to glass microfibre filters with a pore size of less than $0.2 \mu \mathrm{m}$ (Whatman, London, UK), and counting the microspheres in a microscope equipped with transmitted light. All microsphere counting and evaluations of islet volume percentage were performed by an observer unaware of the origin of the samples.

The blood flow values were calculated according to the formula Qorg $=$ Qref $\times$ Norg $/$ Nref where Qorg is organ blood flow $(\mathrm{ml} / \mathrm{min})$, Qref is withdrawal rate of reference sample $(\mathrm{ml} / \mathrm{min})$, Norg is number of microspheres present in the organ and Nref is number of microspheres present in the reference sample. The microsphere contents of the adrenal glands were used to confirm that the microspheres had been adequately mixed in the arterial circulation. A less than $10 \%$ difference in numbers of microspheres between the right and left adrenal gland was taken to indicate sufficient mixing. When the islet blood flow was expressed per islet 
Table 1 Body weight, mean arterial blood pressure, and blood glucose and serum insulin concentrations in wild-type (IAPP $(+/+)$ ) control mice $30 \mathrm{~min}$ after administration of IAPP $(85 \mathrm{nmol} / \mathrm{kg})$ dissolved in $0.2 \mathrm{ml}$ saline or saline alone. All values are means \pm S.E.M. for 11 animals.

\begin{tabular}{llc}
\hline & Saline & IAPP \\
\hline Body weight $(\mathrm{g})$ & $27 \pm 1$ & $24 \pm 1$ \\
Mean arterial blood pressure $(\mathrm{mm} \mathrm{Hg})$ & $86 \pm 3$ & $64 \pm 2^{*}$ \\
Blood glucose concentration $(\mathrm{mmol} / \mathrm{l})$ & $7.4 \pm 0.3$ & $10.4 \pm 0.3^{*}$ \\
Serum insulin concentration $(\mathrm{ng} / \mathrm{ml})$ & $1.9 \pm 0.4$ & $0.9 \pm 0.2^{*}$ \\
\hline
\end{tabular}

${ }^{*} P<0.05$ when compared with saline-treated animals of the same genotype (Student's unpaired $t$-test).

weight, the latter was estimated by multiplying the pancreatic weight with the islet volume fraction of the whole pancreas in each animal (26).

\section{Statistical analysis}

Values are expressed as means \pm S.E.M. When only two groups were compared, the probabilities of chance differences between experimental groups were calculated with Student's two-tailed unpaired t-test. Multiple comparisons between data were performed by using ANOVA and Fisher's protected least significant difference (PLSD) test (Statview; Abacus Concepts, Berkeley, CA, USA). For all comparisons, a probability level of $P<0.05$ was considered to be statistically significant.

\section{Results}

Mean arterial blood pressure, blood glucose and serum insulin concentrations were determined in IAPP $(+/+)$ mice after intravenous administration of saline or $85 \mathrm{nmol} / \mathrm{kg}$ IAPP (Table 1). Administration of IAPP resulted in a significant reduction of the mean arterial blood pressure within $2 \mathrm{~min}$ after administration (not shown). At $30 \mathrm{~min}$ post-injection, the blood pressure in IAPP-treated animals was approximately 25\% lower than that in the saline-treated group (Table 1). Treatment with IAPP also increased blood glucose concentrations and decreased serum insulin concentrations compared with saline treatment (Table 1).

Mean arterial blood pressure was similar in IAPP $(-/-)$ and IAPP $(+/+)$ animals both during the basal state and after saline or glucose administration (Table $2)$. Blood glucose and serum insulin levels were determined in IAPP $(-/-)$ mice and IAPP $(+/+)$ controls $15 \mathrm{~min}$ after an intravenous load of saline or $0.25 \mathrm{ml}$ $30 \%$ D-glucose $(2.5 \mathrm{~g} / \mathrm{kg})$ (Table 2). There were no differences in the basal blood glucose or serum insulin concentrations between saline-treated IAPP $(-/-)$ and IAPP $(+/+)$ mice (Table 2). Glucose administration increased blood glucose and serum insulin concentrations in a similar manner in both IAPP $(-/-)$ and IAPP $(+/+)$ animals (Table 2$)$. The pancreatic islet mass did not differ between the two genotypes (Table 2).

Whole pancreatic, islet, duodenal, ileal, and colonic blood flows were measured in IAPP $(+/+)$ mice $30 \mathrm{~min}$ after intravenous administration of saline or $85 \mathrm{nmol} / \mathrm{kg}$ IAPP (Table 3). Administration of IAPP increased islet blood flow compared with saline treatment, both when expressed per pancreatic weight and per islet weight (Table 3). However, blood flows in whole pancreas, duodenum, ileum or the colon were unaffected by IAPP treatment (Table 3).

Whole pancreatic, islet and intestinal blood flow rates were determined in IAPP $(+/+)$ and IAPP $(-/-)$ mice following intravenous administration of saline or glucose (Table 4). The blood flow rates in the normoglycaemic (saline-treated) state did not differ between IAPP $(-/-)$ and IAPP $(+/+)$ mice (Table 4$)$. Compared with saline-treatment, glucose administration increased islet blood flow in both IAPP $(-/-)$ and IAPP $(+/+)$ mice and to a similar extent, whereas whole pancreatic, duodenal, ileal, and colonic blood flows were unaffected (Table 4).

\section{Discussion}

The blood flow to the pancreatic islets is dependent on complex interactions between hormonal, neural and local factors, with the ultimate goal of maintaining an

Table 2 Body weight, mean arterial blood pressure, blood glucose and serum insulin concentrations, and islet weight in IAPP-deficient $(-/-)$ and wild-type control (+/+) mice $15 \mathrm{~min}$ after administration of $0.25 \mathrm{ml} 30 \%$ (wt/vol) D-glucose or saline. Blood pressure values obtained before the intravenous injections are also given. All values are means \pm S.E.M. for $7-9$ animals.

\begin{tabular}{|c|c|c|c|c|c|}
\hline & & \multicolumn{2}{|c|}{ Wild-type (+/+) } & \multicolumn{2}{|c|}{ IAPP $(-I-)$} \\
\hline & & Saline & Glucose & Saline & Glucose \\
\hline Body weight $(\mathrm{g})$ & & $29 \pm 1$ & $29 \pm 1$ & $32 \pm 1$ & $29 \pm 1$ \\
\hline \multirow[t]{2}{*}{ Mean arterial blood pressure $(\mathrm{mm} \mathrm{Hg})$} & Before & $90 \pm 2$ & $91 \pm 2$ & $90 \pm 3$ & $87 \pm 2$ \\
\hline & After & $94 \pm 3$ & $91 \pm 3$ & $91 \pm 2$ & $84 \pm 2$ \\
\hline Blood glucose concentration (mmol/l) & & $6.7 \pm 0.5$ & $26.3 \pm 1.1^{*}$ & $6.8 \pm 0.5$ & $24.3 \pm 1.9^{*}$ \\
\hline Serum insulin concentration $(\mathrm{ng} / \mathrm{ml})$ & & $2.0 \pm 0.4$ & $4.2 \pm 0.5^{\star}$ & $1.9 \pm 0.3$ & $5.1 \pm 1.0^{*}$ \\
\hline Islet weight (mg) & & $2.93 \pm 0.18$ & $2.91 \pm 0.27$ & $2.83 \pm 0.28$ & $2.96 \pm 0.30$ \\
\hline
\end{tabular}

${ }^{\star} P<0.05$ compared with saline-treated animals of the same genotype (ANOVA and Fischer's PLSD-test). 
Table 3 Whole pancreatic, islet, duodenal, ileal and colonic blood flow in wild-type mice $30 \mathrm{~min}$ after administration of IAPP $(85 \mathrm{nmol} / \mathrm{kg})$ dissolved in $0.2 \mathrm{ml}$ saline or saline alone. All values are means \pm S.E.M. for 11 animals.

\begin{tabular}{|c|c|c|}
\hline & Saline & IAPP \\
\hline Whole pancreatic blood flow $\left(\mathrm{ml} \times \min ^{-1} \times \mathrm{g}_{\text {pancreas }}{ }^{-1}\right)$ & $1.46 \pm 0.32$ & $1.86 \pm 0.33$ \\
\hline Islet blood flow $\left(\mu \mathrm{l} \times \mathrm{min}^{-1} \times \mathrm{g}\right.$ pancreas $\left.{ }^{-1}\right)$ & $12 \pm 3$ & $28 \pm 6^{*}$ \\
\hline Islet blood flow $\left(\mu \mathrm{l} \times \min ^{-1} \times \mathrm{mg}\right.$ islet weight $\left.{ }^{-1}\right)$ & $1.20 \pm 0.30$ & $3.40 \pm 0.80^{*}$ \\
\hline Duodenal blood flow $\left(\mathrm{ml} \times \mathrm{min}^{-1} \times \mathrm{g}^{-1}\right)$ & $3.17 \pm 0.67$ & $3.89 \pm 1.40$ \\
\hline Ileal blood flow $\left(\mathrm{ml} \times \mathrm{min}^{-1} \times \mathrm{g}^{-1}\right)$ & $1.65 \pm 0.40$ & $1.24 \pm 0.39$ \\
\hline Colonic blood flow $\left(\mathrm{ml} \times \min ^{-1} \times \mathrm{g}^{-1}\right)$ & $1.13 \pm 0.21$ & $2.25 \pm 0.79$ \\
\hline
\end{tabular}

${ }^{*} P<0.05$ compared with saline-treated animals (Student's unpaired $t$-test).

adequate islet blood perfusion both for oxygen and nutrient supply of the islet cells, and for the dispersal of insulin to target organs (29). IAPP, which is secreted together with insulin in response to nutrient stimuli, has been suggested to be involved in the pathogenesis of type 2 diabetes by forming islet amyloid $(5,6)$. Several biological activities, including vasoregulatory actions, have been ascribed to IAPP (cf. above), but a major concern when interpreting these results has been whether the reported effects of the peptide reflect pharmacological effects. In the present study, we extended the microsphere technique for measurements of regional blood flow to IAPP-deficient mice (17) to evaluate the possible vascular perturbations that might occur in the pancreas and other splanchnic organs following genetic removal of IAPP. No difference in whole pancreatic blood flow or islet blood flow could be detected in the IAPP-deficient mice when compared with wild-type control mice. Moreover, IAPP deficiency did not influence the glucose-induced increase of islet blood flow. In contrast, a more than doubled islet blood flow was seen after exogenous administration of IAPP to wild-type mice. Indeed, as in previous studies in rats, exogenous administration of IAPP had vascular effects which favoured the islet blood perfusion in the pancreas (21).

Administration of IAPP resulted in increased blood glucose concentrations, as seen also in rats previously (21). An increased blood glucose concentration can selectively increase islet blood flow $(26,30)$, but the degree of hyperglycaemia must be, however, at least
$25-30 \%$ higher than that observed in this study $(26$, 30). Several reasons may explain the increased blood glucose levels, including IAPP-induced insulin resistance in skeletal muscles (7), decreased glucagon secretion (31), increased catecholamine secretion induced by the decreased blood pressure, and decreased insulin secretion $(12-15)$ with concomitant decreased serum insulin concentrations (21), as also observed in the present study. Enhanced insulin release and glucose elimination have been observed in male IAPP $(-/-)$ mice following oral or intravenous glucose administration (17, 32), indicating that IAPP normally restrains glucose-induced insulin secretion. In the present study, no statistically significant differences in blood glucose or serum insulin concentrations were found between IAPP-deficient and control mice either in the basal state or $15 \mathrm{~min}$ after intravenous glucose administration. Nevertheless, there was a clear trend towards increased $(+45 \%)$ glucose-induced insulin release at the latter time point. In addition, in our previous studies $(17,32)$, a lower dose of glucose was given $(1 \mathrm{~g} / \mathrm{kg}$ versus $2.5 \mathrm{~g} / \mathrm{kg})$, raising the possibility that when a supramaximal dose of glucose is used the modulatory effect of IAPP is lost. Also, plasma insulin and glucose levels were determined only at $15 \mathrm{~min}$ after glucose administration; at this time point, the differential dynamics of glucose and insulin homeostasis were not maximally expressed $(17,32)$.

The unaffected islet blood flow rates observed in IAPP-deficient mice could have several other possible

Table 4 Whole pancreatic, islet, duodenal, ileal and colonic blood flow in IAPP-deficient $(-/-)$ and wild-type control $(+/+)$ mice 15 min after administration of $0.25 \mathrm{ml} 30 \%(\mathrm{wt} / \mathrm{vol})$ D-glucose or saline. All values are means \pm S.E.M. for $7-9$ animals.

\begin{tabular}{|c|c|c|c|c|}
\hline & \multicolumn{2}{|c|}{ Wild-type (+/+) } & \multicolumn{2}{|c|}{ IAPP $(-I-)$} \\
\hline & Saline & Glucose & Saline & Glucose \\
\hline Whole pancreatic blood flow $\left(\mathrm{ml} \times \mathrm{min}^{-1} \times \mathrm{g}\right.$ pancreas $\left.^{-1}\right)$ & $1.36 \pm 0.15$ & $1.31 \pm 0.19$ & $1.15 \pm 0.19$ & $1.03 \pm 0.20$ \\
\hline Islet blood flow $\left(\mu \mathrm{l} \times \mathrm{min}^{-1} \times \mathrm{g}\right.$ pancreas $\left.{ }^{-1}\right)$ & $13 \pm 1$ & $22 \pm 4^{*}$ & $12 \pm 2$ & $24 \pm 5^{*}$ \\
\hline Islet blood flow $\left(\mu \mathrm{l} \times \mathrm{min}^{-1} \times \mathrm{mg}\right.$ islet weight $\left.{ }^{-1}\right)$ & $1.05 \pm 0.08$ & $2.32 \pm 0.45^{*}$ & $1.22 \pm 0.18$ & $2.55 \pm 0.47^{*}$ \\
\hline Duodenal blood flow $\left(\mathrm{ml} \times \min ^{-1} \times \mathrm{g}^{-1}\right)$ & $4.05 \pm 0.29$ & $3.65 \pm 0.49$ & $4.52 \pm 0.64$ & $3.52 \pm 0.61$ \\
\hline Ileal blood flow $\left(\mathrm{ml} \times \mathrm{min}^{-1} \times \mathrm{g}^{-1}\right)$ & $1.50 \pm 0.16$ & $1.24 \pm 0.27$ & $1.03 \pm 0.12$ & $1.44 \pm 0.45$ \\
\hline Colonic blood flow $\left(\mathrm{ml} \times \mathrm{min}^{-1} \times \mathrm{g}^{-1}\right)$ & $0.99 \pm 0.09$ & $0.97 \pm 0.15$ & $1.28 \pm 0.32$ & $1.17 \pm 0.30$ \\
\hline
\end{tabular}

${ }^{\star} P<0.05$ compared with saline-treated animals of the same genotype (ANOVA and Fischer's PLSD-test). 
explanations. For instance, since the IAPP nullmutation is present from conception, genetic redundancy or some other form of adaptation with respect to vasoregulation cannot be ruled out. However, the vascular effects observed following nanomolar doses of IAPP $(19,21,33)$, may also represent pharmacological effects; normally, the levels of endogenous IAPP in the circulation in rodents are in the lower picomolar range (34). It should be noted that the calcitonin peptide family consisting of IAPP, calcitonin, the calcitonin-gene related peptides (CGRPs) and adrenomedullin, with different potencies, seem to activate a group of heterodimeric receptors that include the calcitonin receptor (CTR), or a calcitonin receptor-like receptor (CRLR), combined with different receptor-activity-modifying proteins (RAMPs) (35-37). The ligand-specificity of CTR and CRLR is thus thought to depend on which RAMP is involved in the receptor complex. Along this route, at least some of the vascular islet effects observed at high concentrations of IAPP may represent activation of receptors that preferentially bind CGRP or adrenomedullin, both of which are potent vasodilators (cf. 19, 33).

IAPP has been reported to have mitogenic actions, for example on tubular epithelial cells in the kidney (38). To exclude differences in islet mass between the IAPP $(-/-)$ mice and the IAPP $(+/+)$ control mice, possibly caused by such IAPP-mediated mitogenic effects, we determined the islet mass in each animal and also expressed islet blood flow per islet weight; in this case also no differences were found, which is in agreement with our previous finding using image analysis to determine beta-cell mass (32).

In summary, we tested the hypothesis that endogenous IAPP exerts effects in the splanchnic vasculature. No differences in islet blood flow or other splanchnic blood flows were observed when IAPP-deficient mice and wild-type control mice were compared. We therefore conclude that the observed effects after exogenous administration of IAPP probably reflect pharmacological, rather than physiological effects, and that endogenous levels of IAPP are unlikely to exert vascular effects in the pancreatic islets or other splanchnic organs.

\section{Acknowledgements}

The skilled technical assistance of Astrid Nordin is gratefully acknowledged. The study was supported by grants from the Swedish Medical Research Council (72X-109, X0498), the Swedish-American Diabetes Research Program funded by the Juvenile Diabetes Foundation and the Wallenberg Foundation, the Swedish Diabetes Association, the NOVO Nordic Fund, Svenska barndiabetesfonden, Magnus Bergvalls stiftelse, Familjen Ernfors fond, Thurings stiftelse, Lars Hiertas Minne, Goljes Minne and the Swedish Medical Society.

\section{References}

1 Westermark P, Wernstedt C, Wilander E \& Sletten K. A novel peptide in the calcitonin gene related peptide family as an amyloid fibril protein in the endocrine pancreas. Biochemical and Biophysical Research Commununications 1986140 827-831.

2 Westermark P, Wernstedt C, Wilander E, Hayden DW, O'Brien TD \& Johnson KH. Amyloid fibrils in human insulinoma and islets of Langerhans of the diabetic cat are derived from a neuropeptidelike protein also present in islet cells. PNAS 198784 3881-3885.

3 Cooper GJ, Willis AC, Clark A, Turner RC, Sim RB \& Reid KB. Purification and characterization of a peptide from amyloid-rich pancreases of type 2 diabetic patients. PNAS $1987 \mathbf{8 4}$ $8628-8632$.

4 Mulder H, Ekelund M, Ekblad E \& Sundler F. Islet amyloid polypeptide in the gut and pancreas: localization, ontogeny and gut motility effects. Peptides $1997 \mathbf{1 8} 771-783$.

5 Westermark P, Johnson KH, O’Brien TD \& Betsholtz C. Islet amyloid polypeptide: a novel controversy in diabetes research. Diabetologia 199235 297-303.

6 Cooper GJ. Amylin compared with calcitonin gene-related peptide - structure, biology and relevance to metabolic disease. Endocrine Reviews 199415 163-201.

7 Leighton B \& Cooper GJ. Pancreatic amylin and calcitonin generelated peptide cause resistance to insulin in skeletal muscle in vitro. Nature $1988335632-635$.

8 Lawrence JC \& Zhang JN. Control of glycogen synthase and phosphorylase by amylin in rat skeletal muscle - hormonal effects on the phosphorylation of phosphorylase and on the distribution of phosphate in the synthase subunit. Journal of Biological Chemistry 1994269 11595-11600.

9 Koopmans SJ, van Mansfeld AD, Jansz HS, Krans HM, Radder JK, Frolich M et al. Amylin-induced in vivo insulin resistance in conscious rats: the liver is more sensitive to amylin than peripheral tissues. Diabetologia $199134218-224$.

10 Morley JE \& Flood JF. Amylin decreases food intake in mice. Peptides $199112865-869$.

11 Young AA, Gedulin B, Vine W, Percy A \& Rink TJ. Gastric emptying is accelerated in diabetic BB rats and is slowed by subcutaneous injections of amylin. Diabetologia $199538642-648$.

12 Ar'Rajab A \& Ahrén B. Effects of amidated rat islet amyloid polypeptide on glucose-stimulated insulin secretion in vivo and in vitro in rats. European Journal of Pharmacology 1991192 443-445.

13 Wang ZL, Bennet WM, Ghatei MA, Byfield PG, Smith DM \& Bloom SR. Influence of islet amyloid polypeptide and the 8-37 fragment of islet amyloid polypeptide on insulin release from perifused rat islets. Diabetes 199342 330-335.

14 Fürnsinn C, Leuvenink H, Roden M, Nowotny P, Schneider B, Rohac M et al. Islet amyloid polypeptide inhibits insulin secretion in conscious rats. American Journal of Physiology $1994 \mathbf{2 6 7}$ E300-E305.

15 Ahrén B, Oosterwijk C, Lips CJM \& Höppener JWM. Transgenic overexpression of human islet amyloid polypeptide inhibits insulin secretion and glucose elimination after gastric glucose gavage in mice. Diabetologia 199841 1374-1380.

16 Bretherton-Watt D, Gilbey SG, Ghatei MA, Beacham J, Macrae AD \& Bloom SR. Very high concentrations of islet amyloid polypeptide are necessary to alter the insulin response to intravenous glucose in man. Journal of Clinical Endocrinology and Metabolism $1992 \mathbf{7 4}$ $1032-1035$.

17 Gebre-Medhin S, Mulder H, Pekny M, Westermark G, Törnell J, Westermark P et al. Increased insulin secretion and glucose tolerance in mice lacking islet amyloid polypeptide (amylin). Biochemical and Biophysical Research Communications 1998250 271-277.

18 Gebre-Medhin S, Olofsson C \& Mulder H. Islet amyloid polypeptide in the islets of Langerhans: friend or foe? Diabetologia $2000 \mathbf{4 3}$ 687-695.

19 Gardiner SM, Compton AM, Kemp PA, Bennett T, Bose C, Foulkes R et al. Antagonistic effect of human calcitonin gene-related 
peptide $(8-37)$ on regional hemodynamic actions of rat islet amyloid polypeptide in conscious Long-Evans rats. Diabetes 199140 948-951.

20 Brain SD, Wimalawansa S, MacIntyre I \& Williams TJ. The demonstration of vasodilator activity of pancreatic amylin amide in the rabbit. American Journal of Pathology 1990136 487-490.

21 Svensson AM, Sandler S \& Jansson L. Pancreatic islet blood flow in the rat after administration of islet amyloid polypeptide or calcitonin gene-related peptide. Diabetes $1994 \mathbf{4 3} 454-458$.

22 Johnson KH, O’Brien TD, Hayden DW, Jordan K, Ghobrial HK, Mahoney WC et al. Immunolocalization of islet amyloid polypeptide (IAPP) in pancreatic beta cells by means of peroxidaseantiperoxidase (PAP) and protein A-gold techniques. American Journal of Pathology $19881301-8$.

23 Stridsberg M, Sandler S \& Wilander E. Cosecretion of islet amyloid polypeptide (IAPP) and insulin from isolated rat pancreatic islets following stimulation or inhibition of beta-cell function. Regulatory Peptides $1993 \mathbf{4 5} 363-370$.

24 Capecchi MR. Altering the genome by homologous recombination. Science $19892441288-1292$.

25 Ekawa K, Nishi M, Ohagi S, Sanke T \& Nanjo K. Cloning of mouse islet amyloid polypeptide gene and characterization of its promoter. Journal of Molecular Endocrinology 199719 79-86.

26 Carlsson PO, Andersson A \& Jansson L. Pancreatic islet blood flow in normal and obese-hyperglycemic (ob/ob) mice. American Journal of Physiology 1996271 E990-E995.

27 Jansson L \& Hellerström C. A rapid method of visualizing the pancreatic islets for studies of islet capillary blood flow using nonradioactive microspheres. Acta Physiologica Scandinavica 1981 $113371-374$.

28 Weibel ER. Practical methods for biological morphometry. In Stereological Methods, vol 1, pp 101-161. Ed. ER Weibel. London: Academic Press, 1979.

29 Jansson L. The regulation of pancreatic islet blood flow. Diabetes/ Metabolism Reviews $1994 \mathbf{1 0} 407-416$.

30 Jansson L. Glucose stimulation of pancreatic islet blood flow by redistribution of the blood flow within the whole pancreatic gland. Pancreas 19883 409-412.

31 Panagiotidis G, Salehi AA, Westermark P \& Lundquist I. Homologous islet amyloid polypeptide: effects on plasma levels of glucagon, insulin and glucose in the mouse. Diabetes Research and Clinical Practice $1992 \mathbf{1 8} 167-171$.

32 Mulder H, Gebre-Medhin S, Betsholtz C, Sundler F \& Ahrén B. Islet amyloid polypeptide (amylin)-deficient mice develop a more severe form of alloxan-induced diabetes. American Journal of Physiology 2000278 E684-E691.

33 Claing A, Telemaque S, Cadieux A, Fournier A, Regoli D \& D'Orleans-Juste P. Nonadrenergic and noncholinergic arterial dilatation and venoconstriction are mediated by calcitonin generelated peptide-1 and neurokinin-1 receptors, respectively, in the mesenteric vasculature of the rat after perivascular nerve stimulation. Journal of Pharmacological and Experimental Therapeutics $19922631226-1232$.

34 Arnelo U, Permert J, Larsson J, Reidelberger RD, Arnelo C \& Adrian TE. Chronic low dose islet amyloid polypeptide infusion reduces food intake, but does not influence glucose metabolism, in unrestrained conscious rats: studies using a novel aortic catherization technique. Endocrinology 1997138 4081-4085.

35 McLatchie LM, Fraser NJ, Main MJ, Wise A, Brown J, Thompson N et al. RAMPs regulate the transport and ligand specificity of the calcitonin-receptor-like receptor. Nature $1998393333-339$.

36 Christopoulos G, Perry KJ, Morfis M, Tilakaratne N, Gao Y, Fraser NJ et al. Multiple amylin recptors arise from receptor activity modifying protein interaction with the calcitonin receptor gene product. Molecular Pharmacology 199956 235-242.

37 Muff R, Buhlmann N, Fischer JA \& Born W. An amylin receptor is revealed following co-transfection of a calcitonin receptor with receptor activity modifying proteins-1 or -3. Endocrinology 1999 $1402924-2927$.

38 Harris PJ, Cooper ME, Hiranyachattada S, Berka JL, Kelly DJ, Nobes $\mathrm{M}$ et al. Amylin stimulates proximal tubular sodium transport and cell proliferation in the rat kidney. American Journal of Physiology 1997272 F13-F21.

Received 6 April 2001

Accepted 12 September 2001 